\title{
Experience of the Orthopedic Surgeon in the Management of War Victims
}

\author{
Ramzi Ahmad Almurtadi ${ }^{*}$, Abdalla Farag and Sanad Mahmud \\ Department of orthopedic, Faculty of medicine, Omar Al-Mukhtar University, Al-Bayda, Libya.
}

Received: 11 February 2020/ Accepted: 01 September 2020

Doi: https://doi.org/10.54172/mjsc.v35i2.322

\begin{abstract}
Surgery for victims of war is different from surgery for civilian injuries. War wounds are always extremely contaminated, and missiles may cause massive destruction of soft tissues, bones, and other structures. The principles of surgery for war wounds have been known for decades but need to be relearned by each new generation of surgeons working in a war situation. People were not at all prepared for a physical fight. Similarly, the medical institutes were not specially prepared for such a sea of casualties all of a sudden. The study's aim was to analyze the result of our experience in the surgical management of the gunshot patients admitted to Al-Bayda teaching hospital during the first month of the Libyan revolution of February 2011. The total number of patients admitted to Al-Bayda teaching hospital in the period from 16\2\2011 to $16 \backslash 3 \backslash 2011$ was 288 patients. We have done debridement and repair of the wounds and fixation of fractures in different settings and follow-up was carried out for 7 months. Our orthopedic morbidity rate was $9 \%$, and infection was recorded in 30 patients $21 \%$. We, as a team of orthopedic, vascular, and general surgeons, gained a very good exposure and experience to manage war or civilian unrest victims.
\end{abstract}

Keywords: Orthopedic; Gunshot; Civilian; Fractures.

\section{INTRODUCTION}

The evacuation and care of wounded people have evolved throughout the history of warfare. In the recent conflicts in Iraq and Afghanistan, an echeloned approach to trauma care has been instituted (Bagg et al., 2006).

The first aid provided at the point of wounding or at the safest place near the battlefield and rapid evacuation are of vital importance, because mortality and morbidity increase with delay between wounding and treatment. The more effective the first aid and the quicker the evacuation to a hospital, the better will be the final results. If first aid is inadequate or unavailable and the evacuation chain is long, then the outcome will be more disaster (Dufour et al., 1998). Even though the people of Libya were keen for liberation and freedom, the unrest was unprepared and un- precedented. People were not at all prepared for a physical fight. Similarly, the medical institutes were not specially prepared for such a sea of casualties all of a sudden. The maximum number of patients was hospitalized on $17 / 02 / 2011$ approximately $60 \%$ of war injuries involve the limbs and musculoskeletal system, the orthopedic surgeons suppose a pivotal role in the frontline treatment of these injuries, Providing battlefield orthopedic care poses special challenges, because lack of experience and working under difficult conditions, many wounds are unlike those encountered in civilian practice (Covey, 2006).Our teaching hospital was not prepared and did not have enough beds, medicines, materials, necessary equipment, and instruments to meet a large number of patients at a time with various types of gunshot injuries. Our reason for conducting this study is to highlight the unexpected load on or-

*Corresponding Author: Ramzi Ahmad Almurtadi ramzi.almurtdi@omu.edu.ly,. Department of orthopedic, Faculty of medicine, Omar Al-Mukhtar University, Al-Bayda, Libya 
thopedic surgeons' performance during the management of civilian war victims.

\section{MATERIALS AND METHODS}

Our materials depended on the patients admitted to the Al-Bayda teaching hospital managed by what we have at that time without any preparation and lack of instrument, beds, and experience in the management of gunshot patients all of a sudden. The total number of patients admitted to Al-Bayda teaching hospital in the period from $16 \backslash 2 \backslash 2011$ to $16 \backslash 3 \backslash 2011$ was 288 patients, Exclusively 140 patients had musculoskeletal related gunshot injuries. Associated injuries include general surgery, fall-down, and road traffic accidents (Table.1).

Table(1). Number of patients admitted during the period of study $(16 \backslash 2 \backslash 2011-16 \backslash 3 \backslash 2011)$

\begin{tabular}{ll}
\hline \hline Type of trauma & $\begin{array}{l}\text { Number of } \\
\text { patients }\end{array}$ \\
\hline Gunshot [Musculoskeletal] & 140 \\
Gunshot [Abdomen] & 16 \\
Gunshot [abdomen and chest] & 21 \\
Gunshot [ Head and neck ] & 19 \\
Gunshot [ scrotum ] & 2 \\
Road traffic accident & 2 \\
Fall down & 6 \\
Combined [General surgery + & 82 \\
Musculoskeletal] & \\
Total & 288 \\
\hline \hline
\end{tabular}

The patients' ages varied from 15 to 60 years. One 15-year-old patient sustained a gunshot to the left little finger, and there was only one female patient aged 30 yrs who had a gunshot injury to the left shoulder (Table.2).

Table:(2). Age of the patient with type of trauma

\begin{tabular}{|c|c|c|}
\hline $\begin{array}{l}\text { Age of the } \\
\text { patient }\end{array}$ & No. of patients & Type of trauma \\
\hline $5-10$ & 3 & $\begin{array}{l}\text { Road traffic accident }+ \text { fall } \\
\text { down }\end{array}$ \\
\hline $11-15$ & 3 & Fall down + gunshot \\
\hline $16-20$ & 35 & Gunshot + Fall down \\
\hline $21-25$ & 67 & Gunshot \\
\hline $26-30$ & 82 & Gunshot \\
\hline $31-35$ & 40 & Gunshot \\
\hline $36-40$ & 29 & Gunshot \\
\hline $41-45$ & 20 & Gunshot \\
\hline $46-50$ & 4 & Gunshot \\
\hline $51-55$ & 2 & Gunshot \\
\hline $56-60$ & 3 & Gunshot \\
\hline Total & 288 & \\
\hline
\end{tabular}

The majority of patients were admitted in the first week of the revolution, and the maximum number was on battle of the Shahhat battalion (the head battalion in Jabal-Al-Akhdar) on $17^{\text {th }}$ of February 2011 were 56 patients hospitalized (Fig. 1).

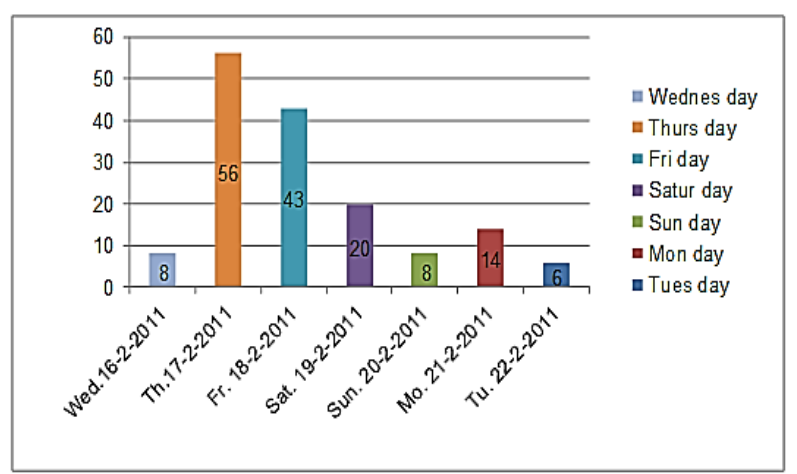

Figure: (1). Number of patient admitted in the first week of revolution.

We, as a team of orthopedic, vascular, and general surgeons, gained the exposure necessary to manage the different types of gunshot injuries explained in (Table.3).

Table: (3). Operations done by the general, vascular, and orthopedic surgeons.

\begin{tabular}{|c|c|c|}
\hline Type of injury & $\begin{array}{l}\text { Surgical opera- } \\
\text { tion }\end{array}$ & Number of patient \\
\hline $\begin{array}{l}\text { Abdominal } \\
\text { gunshot } \\
\text { (16) patients }\end{array}$ & $\begin{array}{l}\text { Nephroctomy } \\
\text { Nephroctomy }+ \\
\text { spleenectomy } \\
\text { Lapratomy with } \\
\text { Bowel injury }\end{array}$ & $\begin{array}{l}\text { (4) patients } \\
\text { (1) patients } \\
\text { (11) patients }\end{array}$ \\
\hline $\begin{array}{l}\text { Thoracic gun- } \\
\text { shot }(21) \\
\text { patients }\end{array}$ & $\begin{array}{l}\text { Chest tub } \\
\text { thoracotomy } \\
\text { Chest superfi- } \\
\text { cial }\end{array}$ & $\begin{array}{l}\text { (11) patients } \\
\text { (5) patients } \\
\text { (5) patients }\end{array}$ \\
\hline $\begin{array}{l}\text { Vascular inju- } \\
\text { ry } \\
\text { (12) patients }\end{array}$ & $\begin{array}{l}\text { Vascular repair } \\
\text { With fracture } \\
\text { fixation } \\
\text { Vascular repair } \\
\text { without fracture } \\
\text { Above knee } \\
\text { amputation }\end{array}$ & $\begin{array}{l}\text { (5) patients } \\
\text { (2) patients }\end{array}$ \\
\hline
\end{tabular}

The following treatment was offered to the patients by the orthopedic team; External fixation in 37 cases $(27 \%)$, Ilizarov external fixation 5 cases $(4 \%), \mathrm{K}$-wire in 5 cases $(4 \%)$, screw in 2 cases $(1 \%)$, dynamic compression plate (DCP) in 1 case $(0.5 \%)$, proximal femoral nail $(\mathrm{PFN})$ 
in 2 cases (1\%), debridement and gypsum splint application in 35 cases (24\%), and superficial wound management done in 53 cases $(38 \%)$ (Table. 4). Following treatment and stabilization of immediate life-threatening conditions, all patients were given antibiotics, but tetanus prophylaxis was not available.

Table: (4). Type of orthopedic fixations

\begin{tabular}{ll}
\hline \hline Type of fixation & No. of patient \\
\hline External Fixation & 37 \\
Ilizarov Ext.Fix & 5 \\
K.Wire & 5 \\
Screw & 2 \\
DCP & 1 \\
PFN & 2 \\
Debridement + Gypsum & 35 \\
Superficial injury (wounds ) & 53 \\
Total & 140 \\
\hline \hline
\end{tabular}

\section{RESULTS}

After a period of follow-up for 7 months, we get the following result; 12 patients had nerve injury, sciatic nerve in three cases, common peroneal nerve in two cases, median nerve in one case, radial nerve in five cases, and ulnar nerve in one case (Table.5).

Table: (5). Number of patients with nerve injury

\begin{tabular}{ll}
\hline \hline Nerve injury & Number of patients \\
\hline Sciatic nerve & 3 \\
Common peroneal nerve & 2 \\
Median nerve & 1 \\
Radial nerve & 5 \\
Ulnar nerve & 1 \\
Total & 12 \\
\hline \hline
\end{tabular}

Our complications, encountered in our series of exclusively 140 patients, had musculoskeletal related gunshot injuries, vascular injury postgunshots were 12 patients. Seven patients had fractures and 5 patients were without fractures, 2 patients had upper limb vascular injury and 10 patients had lower limb vascular injury; out of the 12 patients, 2 patients had above-knee amputations (Table.6).
Table:(6). Complications in the 140 musculoskeletal related gunshot patients

\begin{tabular}{lll}
\hline \hline complications & No, of patients & Percentage \\
\hline Infection after 2 weeks & 30 patients & $21 \%$ \\
$\begin{array}{l}\text { Nonunion } \\
\text { (7 months full up ) }\end{array}$ & 5 patients & $3 \%$ \\
$\begin{array}{l}\text { Failed nerve repair } \\
\text { (7 months full up ) }\end{array}$ & kpatients & $3 \%$ \\
$\begin{array}{l}\text { Stiff knee } \\
(7 \text { months full up ) }\end{array}$ & 2 patients & $1 \%$ \\
$\begin{array}{l}\text { Amputation } \\
\begin{array}{l}\text { Our orthopedic } \\
\text { morbidity rate }\end{array}\end{array}$ & 2 patients & $1 \%$ \\
\hline \hline
\end{tabular}

One patient had a bad mutilating injury of the hand, which usually leads to amputation. We performed debridement and repair, including fixation of fractures by K.wires and plastic surgery in different settings which has resulted in a partially functioning cosmetically acceptable hand.

\section{DISCUSSION}

The range of primary blast injuries includes fractures, amputations, crush injury, burns, cuts, lacerations, acute occlusion of an artery, air embolism- induced injury, compartment syndrome, and others. Secondary, tertiary, and quaternary injuries are also commonly seen in extremity blast injuries. Severe contamination and tissue damage are the major problems (Bumbaširevic et al., 2006). During our work, we have done timely debridement, fracture fixation, post-operative follow-up for seven months, found reasonably results, and we agree with MSF USA (2016). Still, adequate staff, doctors, beds, materials, medicines, instruments, equipment, and orthopedic appliances would have helped us to achieve a much better result, and with the onset of armed conflict in 2011, many foreign workers left the country, so the health system is presently in a critical state.

The AAOS/OTA Extremity War Injuries (EWI II): Development of Clinical Treatment Principles symposium, held in January 2007.

EWI II sessions focused specifically on four separate areas (Defense Casualty Report 2007): 
(1) Prehospital management of extremity wounds

(2) Initial debridement

(3) Early stabilization

(4) Postoperative wound management during their evacuation process.

In comparison to the (EWI II) in our study, we missed the first stage because of the lack of experience and working under difficult conditions and we focused on initial debridement, early stabilization, and postoperative wound management.

Gunshot injuries to the musculoskeletal system in our study constituted 65\%. (EWI II) published that $26 \%$ of these individuals had sustained fractures (Ficke and Pollak. 2007). Whereas (Covey, 2006) published that approximately $60 \%$ of war injuries involve the musculoskeletal system

Amputee care remains complex and challenging. Recent medical, surgical, rehabilitative, and prosthetic advancements have raised both patient and caregiver expectations for outcomes. The rate of major amputation, as a percentage of all battle injuries, was $1 \%$ in our study as two patients had above -knee amputations, which was $12 \%$ during the American Civil War (Potter and Scoville 2006).

We agree with Owens et al. (2006) Current treatment protocols favor the inclusion of timely and stable axial limb fixation, radical debridement of all compromised soft tissues and osseous structures, and early wound closure, in an attempt to minimize overall morbidity and to achieve the highest level of function possible.

\section{CONCLUSION}

Treatment of war or civilian unrest wounds, many of which are devastating in the scope of soft-tissue and bony injury, requires a team approach using hypotensive resuscitation, damage-control orthopedics, newer techniques of hemostasis and vacuum-assisted wound closure, and advanced reconstruction. Current challenges include prevention of infection, het- erotopic ossification, good cosmetic and functional results, adequate rehabilitation, physical therapy, and occupational therapy services, as well as psychiatric, or other services, when necessary

We strongly recommend having a specialized trauma center with adequate facilities, material, and trained qualified personal.

We, as a team of orthopedic, vascular and general surgeons, gained very good exposure and experience to manage the war or civilian unrest victims in 2011.

\section{REFERENCES}

Bagg, M. R., Covey, D. C., \& Powell, E. T. I. (2006). Levels of Medical Care in the Global War on Terrorism. JAAOS Journal of the American Academy of Orthopaedic Surgeons, 14(10), S7-S9. https://journals.lww.com/jaaos/Fulltext/ 2006/00001/Levels of Medical_Care i n the Global War_on.3.aspx

Bumbaširevic, M., Lesic, A., Mitkovic, M., \& Bumbaširevic, V. (2006). Treatment of Blast Injuries of the Extremity. JAAOS Journal of the American Academy of Orthopaedic Surgeons, 14(10), S77S81.

https://journals.lww.com/jaaos/Fulltext/ 2006/00001/Treatment of Blast Injuri es of the Extremity.18.aspx

Covey, D. C. (2006). Combat Orthopaedics: A View from the Trenches. JAAOS Journal of the American Academy of Orthopaedic Surgeons, 14(10), S10S17.

https://journals.1ww.com/jaaos/Fulltext/ 2006/00001/Combat_Orthopa dics_ A View From the Trenches.4.aspx

Dufour, D. , Kromann, S. Jensen, Owensmith,M. , Salmela, J., Stening, G.F.and zetterstr zetterstr, B. (1998). Surgery for victims of war. International Com- 
mittee of the Red Cross Geneva, October (third edition) .p225

Defense Casualty Report 20 August (2007) .Available :http://www.defenselink.mil/news/casua lty.

Ficke, J. R., \& Pollak, A. N. (2007). Extremity War Injuries: Development of Clinical Treatment Principles. JAAOS - Journal of the American Academy of Orthopaedic Surgeons, 15(10), 590-595. https://journals.lww.com/jaaos/Fulltext/ 2007/10000/Extremity War Injuries Development of Clinical.3.aspx

Medicines Sans Frontiers. MSF USA, April 26, 2016

Owens, B. D., Wenke, J. C., Svoboda, S. J., \& White, D. W. (2006). Extremity Trauma Research in the United States Army.JAAOS - Journal of the American Academy of Orthopaedic Surgeons, 14(10), S37-S40. https://journals. lww.com/ jaaos/Fulltext /2006/00001/Extremity_Trauma_Resear ch in the United States.8.aspx

Potter, B. K., \& Scoville, C. R. (2006). Amputation is not isolated: an overview of the US Army Amputee Patient Care Program and associated amputee injuries. $J$ Am Acad Orthop Surg, 14(10 Spec No.), S188-190. https://doi.org/10.5435/00124635200600001-00041 


\title{
خبرة جراحة العظام في معالجة ضحايا الحروب
}

\author{
رمزي أحمد الحاسي، عبد الله فرج، سند محمود \\ قسم العظام، كلية الطب البشري، جامعة عمر الدختار، البيضاء-ليييا

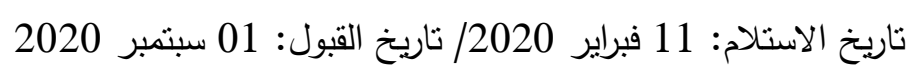 \\ https://doi.org/10.54172/mjsc.v35i2.322 :Doi
}

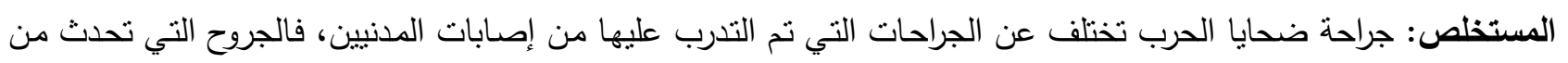

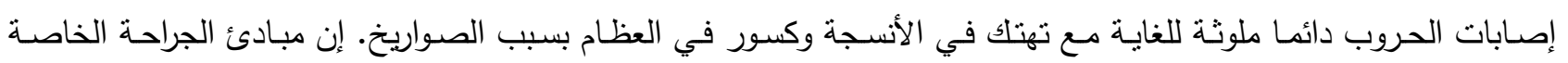

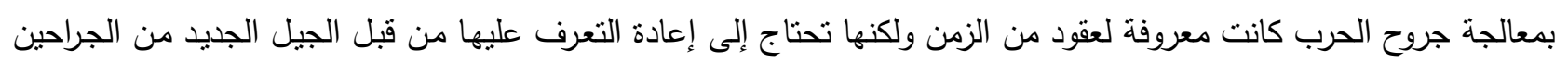

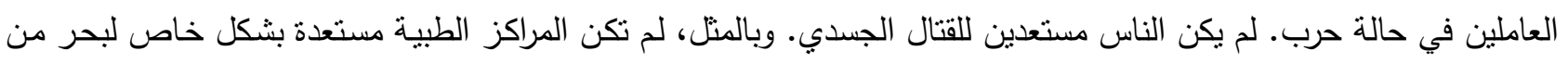

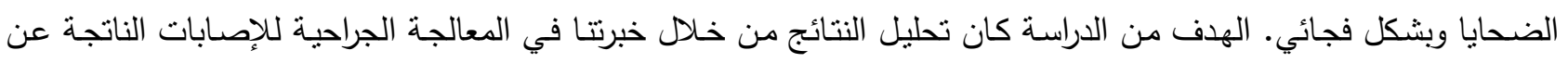

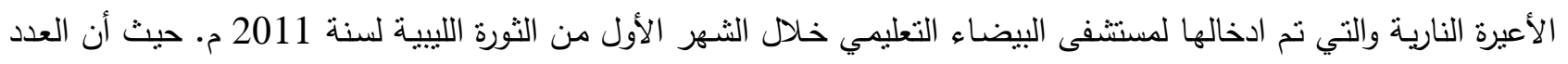

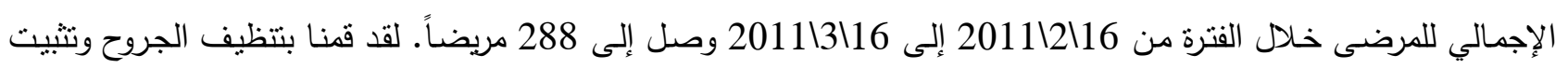

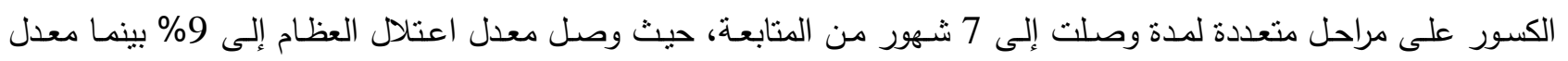

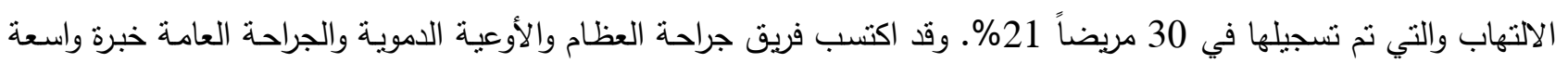
في التعامل مع ضحايا الحرب واصابات الدنيين. الكلمات المفتاحية: طبيب العظام، الطلقات النارية، الدنيين، الكسور . 